\title{
Influence of preparation method of sulfated zirconia nanoparticles for levulinic acid
}

\section{esterification}

Margarita Popova ${ }^{a *}$, Ágnes Szegedi ${ }^{b}$, Hristina Lazarova ${ }^{a}$, Momtchil Dimitrov ${ }^{\mathrm{a}}$, Yuri Kalvachev ${ }^{\mathrm{c}}$, Genoveva Atanasovad $^{\mathrm{d}}$, Alenka Ristiće ${ }^{\mathrm{e}}$ Nicole Wilde ${ }^{\mathrm{f}}$, Roger Gläser ${ }^{\mathrm{f}}$

${ }^{a}$ Institute of Organic Chemistry with Centre of Phytochemistry, Bulgarian Academy of Science, 1113 Sofia, Bulgaria

${ }^{b}$ Research Centre for Natural Sciences, Hungarian Academy of Sciences, Institute of Materials and Environmental Chemistry, 1117 Budapest, Magyar tudósok körútja 2, Hungary

'Institute of Mineralogy and Crystallography, Bulgarian Academy of Sciences, 1113 Sofia, Bulgaria ${ }^{d}$ Institute of General and Inorganic Chemistry, Bulgarian Academy of Sciences, 1113 Sofia, Bulgaria

${ }^{e}$ National Institute of Chemistry Slovenia, Hajdrihova 19, 1001 Ljubljana, Slovenia

${ }^{f}$ Universität Leipzig, Institute of Chemical Technology, Linnéstr. 3, 04103 Leipzig, Germany

*Corresponding autor: mpopova@orgchm.bas.bg

\begin{abstract}
Zirconia nanomaterials were prepared by hydrothermal synthesis with or without template and were modified by post synthesis method with sulfate groups. The materials were thoroughly characterized by X-ray powder diffraction (XRD), $\mathrm{N}_{2}$ physisorption, UV-Vis spectroscopy, TG analysis and XPS spectroscopy. The catalytic performance of nanosized mesoporous $\mathrm{ZrO}_{2}$ catalysts and their sulfated modifications was studied in levulinic acid (LA) esterification with ethanol. The sulfate group's dispersion was predetermined by the use of template during the mesoporous zirconia synthesis. A relation between sulfate groups leaching and the applied synthesis conditions (with or without template) of the zirconia nanoparticles was found. Sulfated materials showed significantly higher activity compared to non-sulfated ones. Furthermore, it has been found that the presence of
\end{abstract}


template during the mesoporous $\mathrm{ZrO}_{2}$ nanoparticles preparation influences significantly the zirconia state and catalytic performance in levulinic acid esterification.

Keywords: ethyl levulinate, esterification, nanosized sulfated zirconia, biomass utilization

\section{Introduction}

Valorization of lignocellulosic biomass by its transformation into valuable chemicals or liquid fuels has attracted great attention in recent years [1-5]. Levulinic acid (LA) is one of the promising platform molecules obtained from lignocellulosic biomass and used for the production of fuel additives, polymers and fine chemicals [6-15]. LA can be further converted into levulinate esters, $\gamma$ valerolactone, 1,4-pentanediol and 5-nonanone (via pentanoic acid) as well as diphenolic acid as an intermediate for the synthesis of epoxy resins and poly-carbonates [16-19]. Levulinate esters are also useful compounds that can be used as fuel additives, solvents and plasticizers [19-22]. Therefore, they have the potential to reduce the consumption of petroleum-derived fossil fuels. Levulinate esters are produced by esterification of LA with alcohols utilizing mineral acids such as $\mathrm{HCl}, \mathrm{H}_{2} \mathrm{SO}_{4}$ and $\mathrm{H}_{3} \mathrm{PO}_{4}$.

However, these mineral acids possess several drawbacks, e.g., high toxicity, corrosiveness and a difficult recovery. Therefore, substitution of homogeneous catalysts by heterogeneous analogues that are easily separable and reusable is an important task. Various solid acids have been used for esterification reactions, e.g., zeolites, Wells-Dawson heteropolyacids and sulfated oxides $\left(\mathrm{SO}_{4}{ }^{2-} / \mathrm{ZrO}_{2}, \mathrm{SO}_{4}{ }^{2-} / \mathrm{Nb}_{2} \mathrm{O}_{5}, \mathrm{SO}_{4}{ }^{2-} / \mathrm{TiO}_{2}, \mathrm{SO}_{4}{ }^{2-} / \mathrm{SnO}_{2}\right)[4,6,13,15,19,20]$. The activity of sulfated oxides can be improved by optimizing preparation conditions, which can influence the number of acid sites and the dispersion state of the sulfate species. One possible approach to enhance acid sites dispersion is the introduction of mesopores in the metal oxides via micelle templating [23, 24, 26, 27]. The improvement of acid catalyst stability was achieved by incorporation of a moderate amount of $\mathrm{Si}$ (up to $30 \mathrm{~mol} \% \mathrm{Si}$ per $\mathrm{Zr}$ ) into sulfated $\mathrm{ZrO}_{2} .{ }^{15}$ The method of the preparation of sulphated zirconia plays a crucial role. The physico-chemical properties of the obtained sulfated zirconia depend on the $\mathrm{ZrO}_{2}$ synthesis conditions and method for sulfation. Parvulescu et al. [13] 
applied two ways for sulfated zirconia catalyst preparation: (i) colloidal sol-gel technique in the presence of $\mathrm{H}_{2} \mathrm{SO}_{4}$ or $\mathrm{CH}_{3} \mathrm{COOH}$ as peptizing agent and (ii) impregnation of $\mathrm{Zr}(\mathrm{OH})_{4}$. Arata et al. [28] used zirconium sulfate as a $\mathrm{Zr}$ precursor in one-step procedure but the sulfate content cannot be controlled. Tichit et al. also reported one-step sol-gel synthesis of sulfated zirconia catalysts by the method in which sulfuric acid was added to the solution of zirconium alkoxide in n-propanol and then was hydrolyzed [29]. Ward and Ko reported a different way to prepare zirconia sulfate aerogels in a one-step procedure using the sol-gel technique and the zirconium alkoxide precursors [30].

In the present study nanosized $\mathrm{ZrO}_{2}$ functionalized by sulfate groups were prepared with or without template hydrothermal method and were studied in levulinic acid esterification with ethanol. The influence of the method of the nanosized $\mathrm{ZrO}_{2}$ preparation on the catalytic activity towards levulinate esters was discussed.

\section{Experimental}

\subsection{Synthesis of nanosized $\mathrm{ZrO}_{2}$ materials}

Nanosized $\mathrm{ZrO}_{2}$ samples were synthesized using template-assisted or template-free precipitation technique followed by hydrothermal treatment step according to a procedure reported by Hudson at al. with some modifications [23]. Cetyltrimethylammonium bromide (CTMABr) was used as a template. The surfactant/zirconia molar ratio was 10 and $\mathrm{pH}$ value of the gel was adjusted to 11.5 by adding the $25 \% \mathrm{NH}_{4} \mathrm{OH}$. The mixture was then stirred in a thermostatically controlled waterbath at $40^{\circ} \mathrm{C}$ for $90 \mathrm{~min}$. Materials were hydrothermally treated at 100 and $140^{\circ} \mathrm{C}$ for $24 \mathrm{~h}$. The final material was filtered, dried at room temperature and later calcined up to $300^{\circ} \mathrm{C}$ (15 hours at $\left.300^{\circ} \mathrm{C}\right)$. The obtained samples are designated as follows: $\mathrm{ZrO}_{2}(\mathrm{x}) \mathrm{T}$ where $\mathrm{x}=100$ or $140^{\circ} \mathrm{C}$ is the temperature of hydrothermal synthesis and $\mathrm{T}$ is for samples synthesized in the presence of template.

\subsection{Functionalization of nanosized $\mathrm{ZrO}_{2}$ by $\mathrm{SO}_{4}{ }^{2-}$ groups}

Nanosized $\mathrm{ZrO}_{2}$ samples were mixed with $10 \% \mathrm{H}_{2} \mathrm{SO}_{4}$ solution $\left(40 \mathrm{ml} / 1 \mathrm{~g} \mathrm{ZrO}_{2}\right)$ at room temperature for $2 \mathrm{~h}$. The suspension was dried at ambient conditions and calcined at $500^{\circ} \mathrm{C}$ for $3 \mathrm{~h}$. 
The samples after sulfation are denoted as $\mathrm{SO}_{4}{ }^{2-} / \mathrm{ZrO}_{2}(\mathrm{x}) \mathrm{T}$ (x-hydrothermal temperature) with template, and $\mathrm{SO}_{4}{ }^{2-} / \mathrm{ZrO}_{2}(\mathrm{x})$ without template. Bulk $\mathrm{ZrO}_{2}$ (purchased by Sigma Aldrich) was sulfated and calcined at $500^{\circ} \mathrm{C}$ for comparison to the sulfated $\mathrm{ZrO}_{2}$ nanoparticles. The sample was denoted as $\mathrm{SO}_{4}{ }^{2-} / \mathrm{bulkZrO}_{2}$.

\subsection{Characterization}

The X-ray powder diffraction (XRD) patterns were recorded on a PANalytical X'Pert PRO (HTK) high-resolution diffractometer using $\mathrm{Cu} \mathrm{K \alpha 1}$ radiation $\left(1.5406 \AA\right.$ ) in the $2 \theta$ range from $5^{\circ}$ to $60^{\circ}$ (100 s per step $0.016^{\circ}$ ) for the samples and for the sample holder using a fully opened $\mathrm{X}^{\prime}$ Celerator detector.

The UV-Vis spectra were recorded on a Jasco V-650 UV-Vis spectrophotometer equipped with a diffuse reflectance unit.

Nitrogen physisorption measurements were carried out at $-196^{\circ} \mathrm{C}$ using Tristar 3000 Micromeritics volumetric adsorption analyzer. Before the adsorption analysis samples were outgassed under vacuum for $2 \mathrm{~h}$ at $200^{\circ} \mathrm{C}$ in the port of the adsorption analyzer. The BET specific surface area was calculated from adsorption data in the relative pressure range from 0.05 to 0.21 . The total pore volume was estimated on the basis of the amount adsorbed at a relative pressure of 0.96 . The pore size distributions (PSDs) were calculated from nitrogen adsorption data using an algorithm based on ideas of Barrett, Joyner, and Halenda $(\mathrm{BJH})$. The mesopore diameters were determined as the maxima on the PSD for given samples.

The composition and the chemical properties of the selected samples were analyzed by X-ray photoelectron spectroscopy (XPS). The measurements were carried out on AXIS Supra electronspectrometer (Kratos Analitycal Ltd.) using monochromatic AlKa radiation with photon energy of $1486.6 \mathrm{eV}$. The energy calibration was performed by normalizing the $\mathrm{C} 1 \mathrm{~s}$ line of adsorbed adventitious hydrocarbons to $284.6 \mathrm{eV}$. The binding energies (BE) were determined with an accuracy of $\pm 0.1 \mathrm{eV}$. The chemical composition of the samples was determined monitoring the areas and binding energies of $\mathrm{O} 1 \mathrm{~s}, \mathrm{Zr} 3 \mathrm{~d}$ and $\mathrm{S} 2 \mathrm{p}$ photoelectron peaks. Using the commercial data- 
processing software of Kratos Analytical Ltd. the concentrations of the different chemical elements (in atomic \%) were calculated by normalizing the areas of the photoelectron peaks to their relative sensitivity factors.

The thermogravimetric measurements were performed with DTA-TG analyzer SETSYS2400, SETARAM under the following conditions: temperature range $25-1000^{\circ} \mathrm{C}$, static air atmosphere, heating rate of $5^{\circ} \mathrm{C} / \mathrm{min}$.

FT-IR experiments were performed with Nicolet Compact 640 spectrometer by the self-supported wafer technique with pyridine $(\mathrm{Py})(7 \mathrm{mbar})$ as probe molecule. Self-supported pellets $(10 \times 20 \mathrm{~mm})$ were pressed from the samples, placed into the IR cell, heated up to $300^{\circ} \mathrm{C}$ in high vacuum $\left(10^{-6}\right.$ mbar) with a rate of $10^{\circ} \mathrm{C} / \mathrm{min}$ and dehydrated for $1 \mathrm{~h}$. Following 30 min contact with $\mathrm{Py}$ at $100^{\circ} \mathrm{C}$ the sample was evacuated subsequently at $100,200,300^{\circ} \mathrm{C}$ for $30 \mathrm{~min}$. After each evacuation step a spectrum was recorded at IR beam temperature with a resolution of $2 \mathrm{~cm}^{-1}$. The spectra were normalized to $20 \mathrm{mg} / \mathrm{cm}^{2}$ weight of the wafers for comparison.

\subsection{Catalytic activity measurements}

Prior to the catalytic experiments samples were pretreated ex-situ for 1 hour at $140^{\circ} \mathrm{C}$. A twonecked round-bottom flask $(\mathrm{V}=100 \mathrm{ml})$ equipped with a septum for sampling and a reflux condenser was used to perform the esterification reaction batchwise with magnetic stirring (300 rpm). In a typical experiment, the reactor was charged with $2 \mathrm{~g} \mathrm{LA}$ and $0.050 \mathrm{~g}$ catalyst $(2.5 \mathrm{wt} . \%$ catalyst/LA) while the LA/ethanol weight ratio was maintained 1:5. The reactor was placed in an oil bath and heated to the desired reaction temperature $\left(70^{\circ} \mathrm{C}\right)$ for $8 \mathrm{~h}$. Samples were taken every hour from the reaction mixture and analyzed using HP-GC with a WCOT FUSED SILICA 25m $x$ 0.25mm COATING CP-SIL 43CB column. 

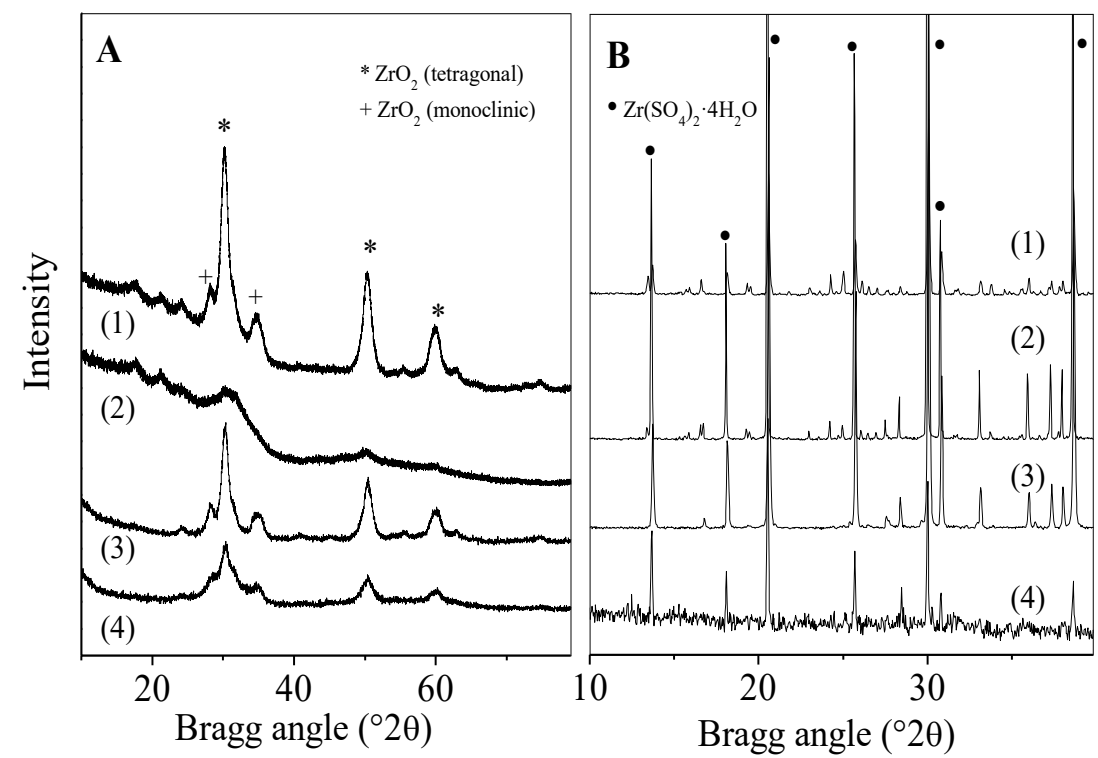

Fig. 1 XRD patterns of zirconia samples - (1) $\mathrm{ZrO}_{2}(140) \mathrm{T}$, (2) $\mathrm{ZrO}_{2}(100) \mathrm{T}$, (3) $\mathrm{ZrO}_{2}(140)$, (4) $\mathrm{ZrO}_{2}(100)(\mathrm{A})$ and their sulfated analogs thermally treated at $500^{\circ} \mathrm{C}(\mathrm{B})$.

\section{Results and Discussion}

\subsection{Physico-chemical properties}

XRD patterns of the studied catalysts are shown in Fig. 1. $\mathrm{ZrO}_{2}$ supports (Fig. 1A) represent reflections typical mainly of tetragonal $\mathrm{ZrO}_{2}$ phase (space group $\mathrm{P} 42 / \mathrm{nmc}$ ). Less intensive reflections of monoclinic phase $(\mathrm{P} 21 / \mathrm{c})$ are also present. The average crystallite size of the samples (calculated by Scherrer equation) is about 5-7 nm, except for $\mathrm{ZrO}_{2}(100) \mathrm{T}$ with very small crystallites of 1-2 nm particles. The presence of template and $100^{\circ} \mathrm{C}$ of hydrothermal synthesis lead to the formation of smaller $\mathrm{ZrO}_{2}$ nanoparticles. It seems, that the higher temperature $\left(140^{\circ} \mathrm{C}\right)$ favors the crystallization process regardless of the presence/absence of template and $\mathrm{ZrO}_{2}$ particles with 5$7 \mathrm{~nm}$ size are formed. By sulfation procedure and thermal treatment at $500^{\circ} \mathrm{C}$, formation of highly crystalline zirconium sulfate and its hydrated form, $\mathrm{ZrSO}_{4} \cdot 4 \mathrm{H}_{2} \mathrm{O}$ can be observed (Fig. 1B). 

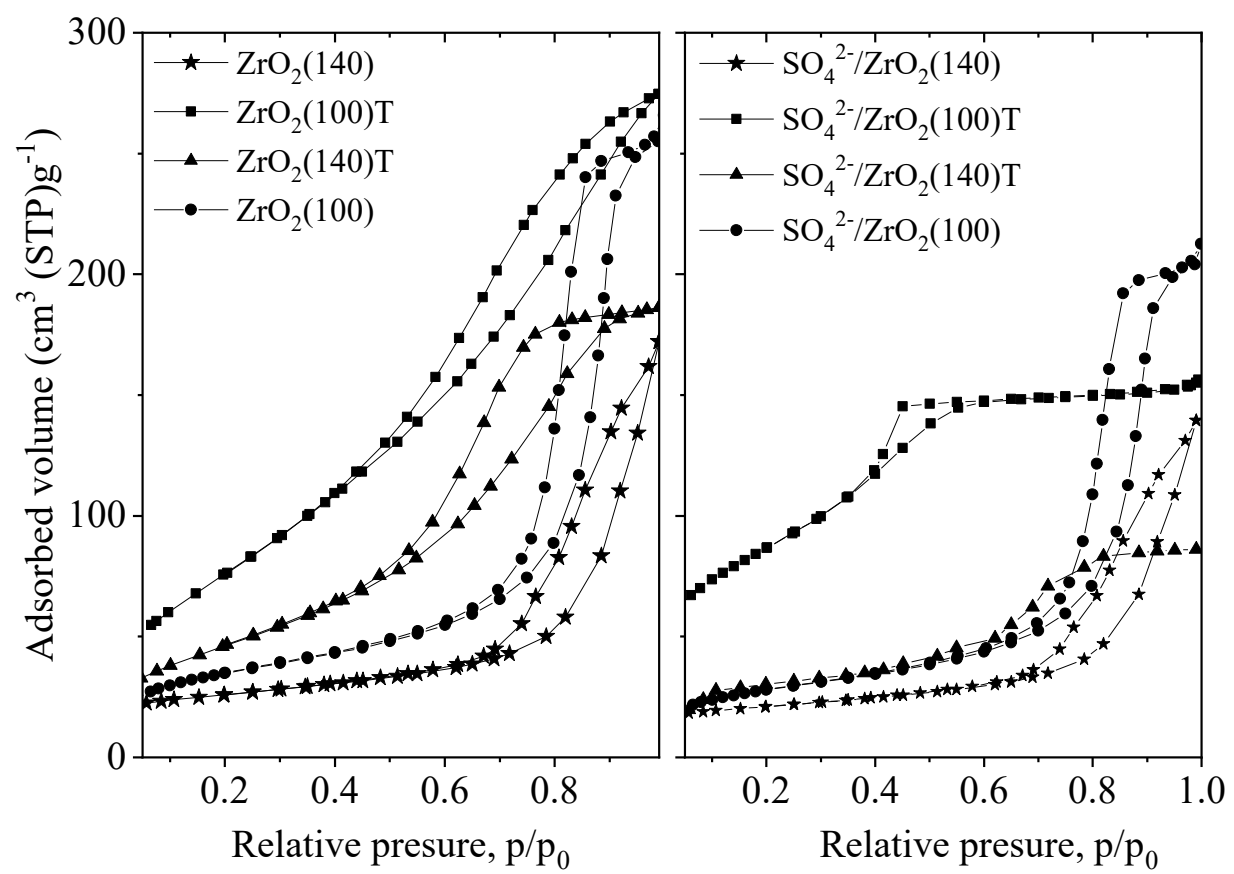

Fig. $2 \mathrm{~N}_{2}$ physisorption isotherms and pore size distribution curves of zirconia samples and their sulfated analogs.

The textural parameters from nitrogen adsorption/desorption isotherms of the parent and sulfated zirconia samples are listed in Tables 1 and 2. The isotherms are of IV type (Fig.2), characteristic of mesoporous materials, and similar to those usually found in inorganic oxides synthesized by the hard-templating route [24-26]. By using the template, samples with higher surface area and pore volume can be prepared. It can be observed that with the increase of the temperature of hydrothermal treatment the surface area and pore volume decreased. Sulfation procedure followed by thermal treatment at $500^{\circ} \mathrm{C}$ resulted in a change of textural properties of all the samples. Specific surface area as well as pore volume decreased after the sulfation procedure for all samples. However, the decrease of surface area is less pronounced for samples prepared after hydrothermal treatment at $100^{\circ} \mathrm{C}$.

TEM images of $\mathrm{SO}_{4}{ }^{2-} / \mathrm{ZrO}_{2}(100)$ (Fig.3, A-B) and $\mathrm{SO}_{4}{ }^{2-} / \mathrm{ZrO}_{2}(100) \mathrm{T}$ (Fig.3 C-D) samples after sulfation show the formation of zirconium sulfate with bigger particle size because of 


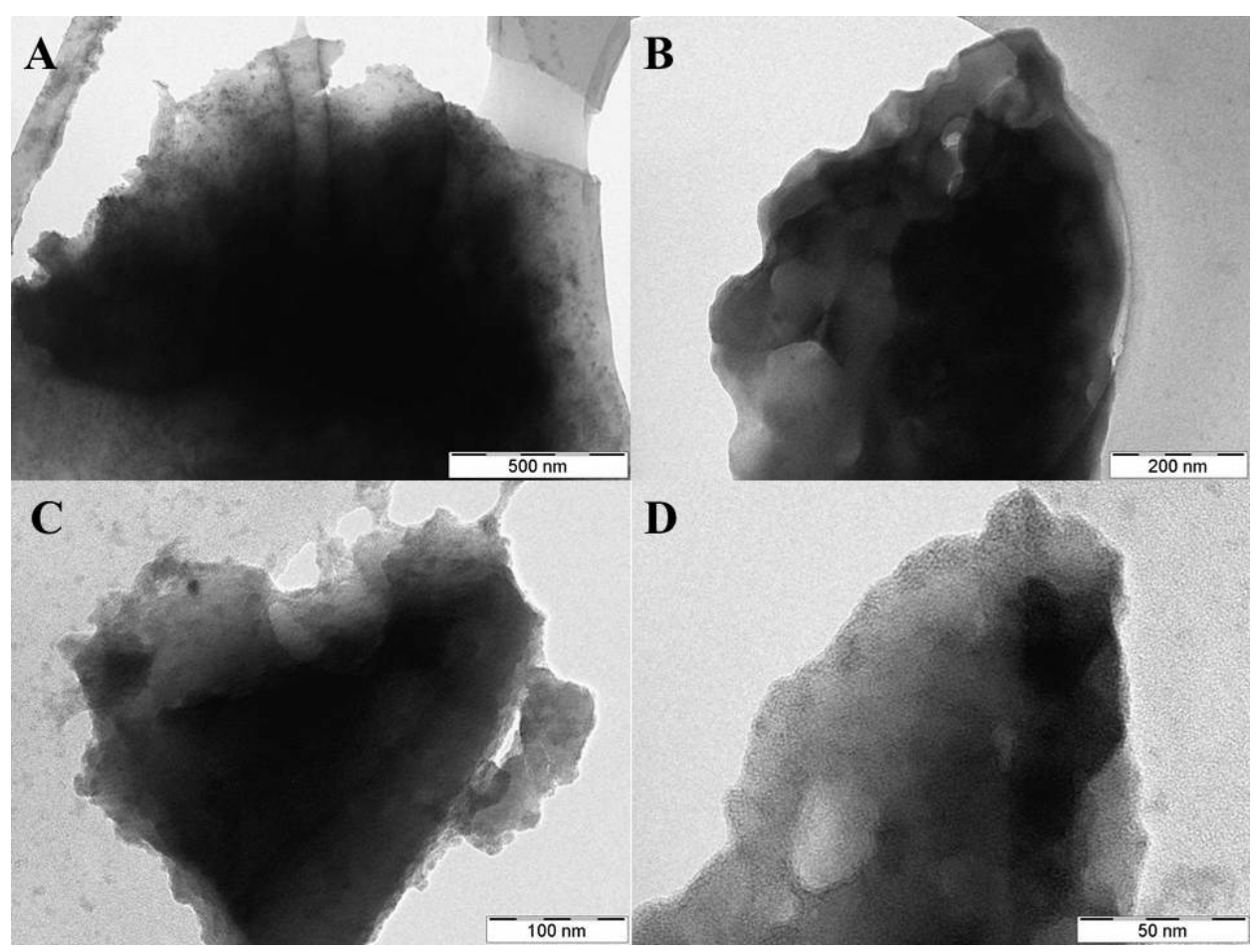

Fig. 3 TEM images of $\mathrm{ZrO}_{2}(100) \mathrm{T}$ and $\mathrm{ZrO}_{2}(100)$ samples.

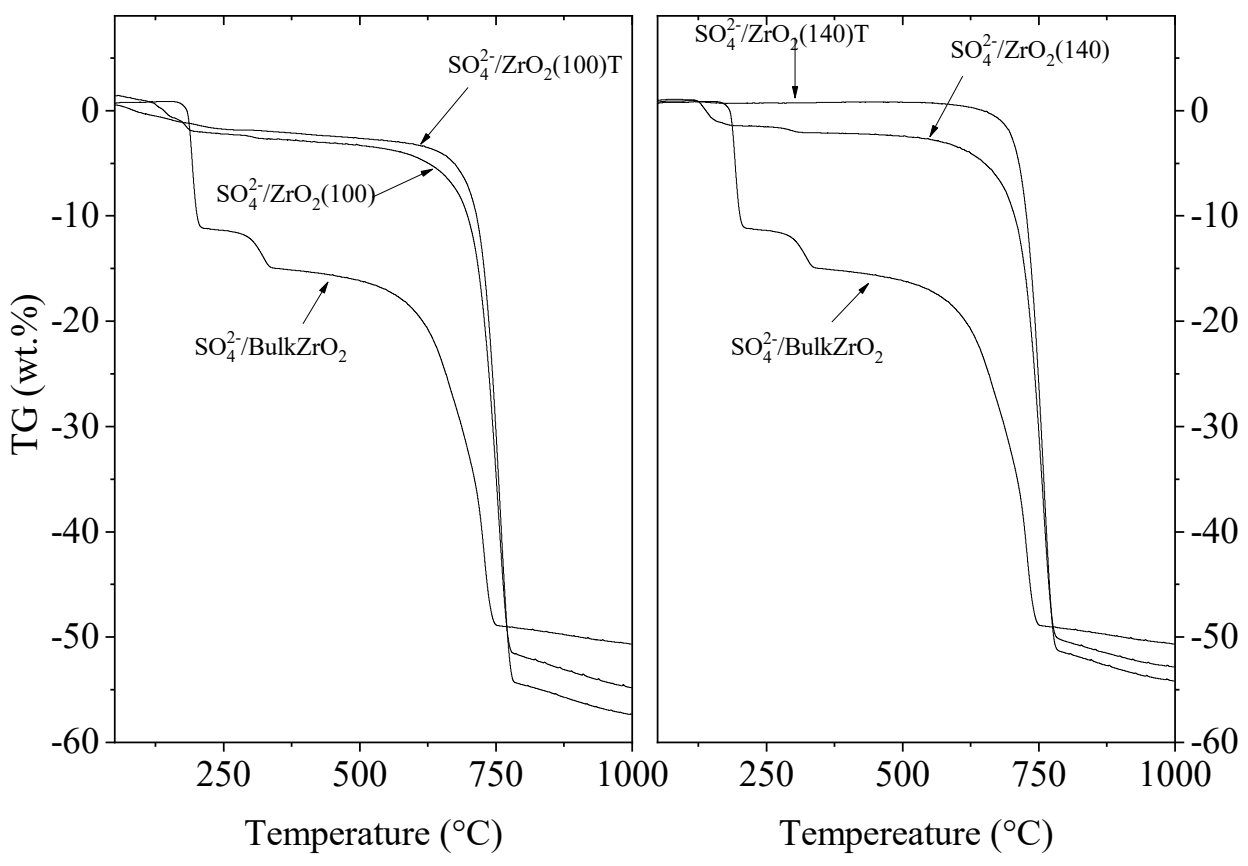

Fig. 4 TG/DTG curves of the sulfated zirconia samples prepared at different hydrothermal temperatures with or without template compared to commercial bulk sulfated zirconia. 


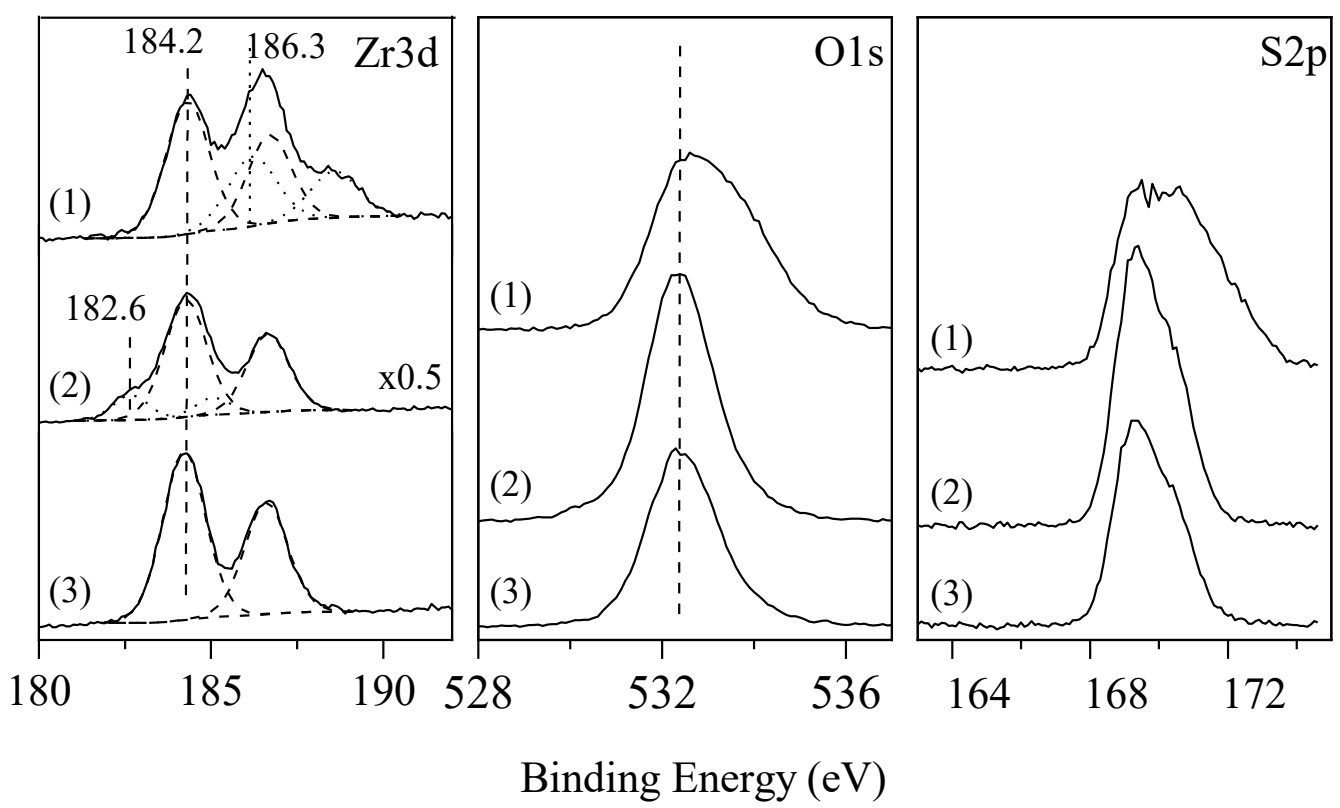

Fig. $5 \mathrm{Zr} 3 \mathrm{~d}$, O $1 \mathrm{~s}$ and $\mathrm{S} 2 \mathrm{p}$ XPS spectra of $\mathrm{SO}_{4}{ }^{2-} / \mathrm{ZrO}_{2}$ samples - (1) $\mathrm{SO}_{4}{ }^{2-} / \mathrm{ZrO}_{2}(140)(500)$, (2) $\mathrm{SO}_{4}{ }^{2-} / \mathrm{ZrO}_{2}(100) \mathrm{T}(500),(3) \mathrm{SO}_{4}{ }^{2-} / \mathrm{ZrO}_{2}(140) \mathrm{T}(500)$.

agglomeration process. The preservation of mesoporosity is better expressed in the case of $\mathrm{SO}_{4}{ }^{2-}$ ${ }^{\prime} \mathrm{ZrO}_{2}(100) \mathrm{T}(\mathrm{C}-\mathrm{D})$.

TG/DTG plots of sulfated $\mathrm{ZrO}_{2}$ nanoparticles are shown in Fig. 4 and the calculated weight loss due to sulfate group decomposition is presented in Table 2 . The weight loss registered above $600^{\circ} \mathrm{C}$ is due to the decomposition of $\mathrm{SO}_{4}{ }^{2-}$ groups. All samples show similar weight loss (Table 2) regardless of the temperature of their hydrothermal synthesis and the presence of template during the synthesis procedure. The calculated amount of sulfate groups is about 50-54 wt. \%. Two additional temperature steps below $600^{\circ} \mathrm{C}$ were registered for $\mathrm{SO}_{4}{ }^{2-} /$ bulkZrO${ }_{2}$. They are associated with $\mathrm{SO}_{4}{ }^{2-}$ groups weakly bonded to the bulk $\mathrm{ZrO}_{2}$.

The nature of the surface environment within the $\mathrm{SO}_{4}{ }^{2-} / \mathrm{ZrO}_{2}$ samples was explored by XPS (Fig.5, Table 3). Zirconium 3d spectra (Fig. 5A) of the samples consist of the doublet $3 \mathrm{~d}_{5 / 2}, 3 \mathrm{~d}_{3 / 2}$ spin-orbit splitting. The spectrum of the $\mathrm{SO}_{4}{ }^{2-} / \mathrm{ZrO}_{2}(100) \mathrm{T}(500)$ sample shows an additional peak with low intensity at $182.6 \mathrm{eV}$. According to Ardizzone [27], the $\mathrm{Zr}$ region of the samples after sulfation 

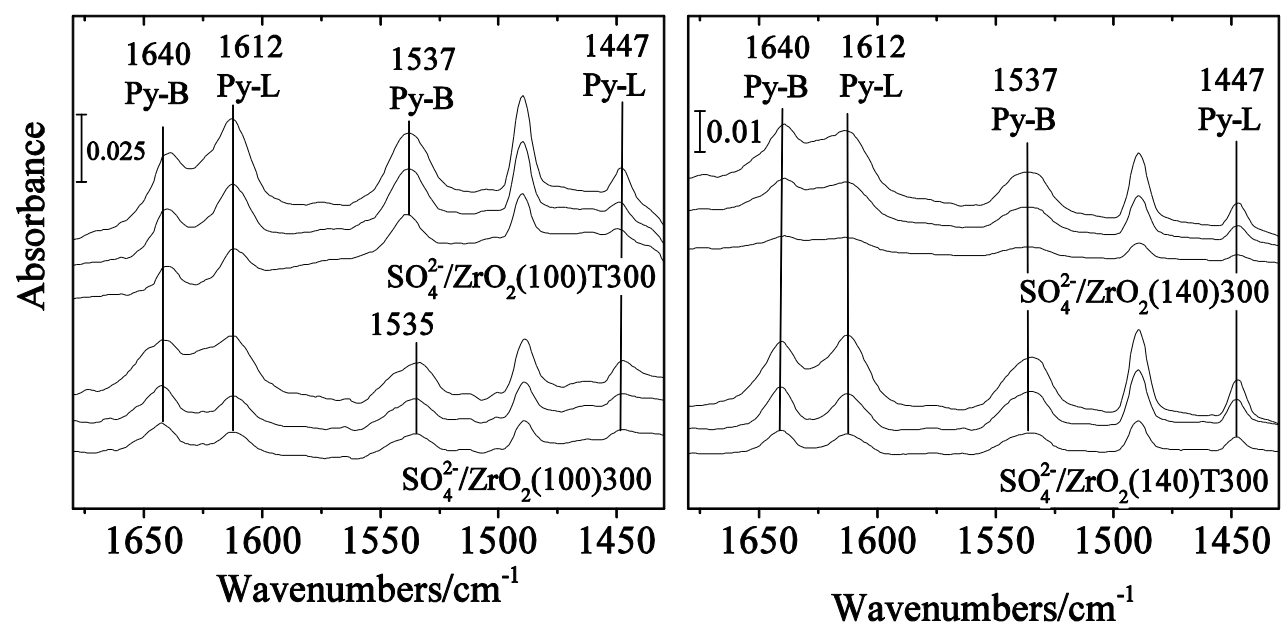

Fig. 6 FT-IR spectra of adsorbed pyridine on the sulfated zirconia materials. Self-supported pellets were pretreated at $350^{\circ} \mathrm{C}$ in vacuum and contacted with Py $(7$ mbar $)$ for $30 \mathrm{~min}$. Spectra were collected after Py desorption at $100,200,300^{\circ} \mathrm{C}$ for $30 \mathrm{~min}$, shown from top to bottom for each sample.

procedure had 3d5/2 component at $182.8 \mathrm{eV}$ (monoclinic phase) and in the region 183.3-186 eV (tetragonal phase) corresponding to Zr (IV) connected to electron-attractive groups [31-33]. After the sulfation the presence of sulfur into two components at 169 and $170 \mathrm{eV}$ was detected, corresponding to deprotonated sulfated species and protonated ones, respectively. Mainly deprotonated sulfate species connected to the bidentate complex formation are registered in our samples. The asymmetric peak in the $\mathrm{O} 1 \mathrm{~s}$ region for all samples (Fig. 5) shows the presence of one main component, which is attributed to oxygen in sulfates $(532.4 \mathrm{eV})$ and a low intensive peak, registered at higher $\mathrm{BE}(534 \mathrm{eV})$ and it is due to surface $\mathrm{OH}$ groups.

The components of the spectra determined by deconvolution are presented in Table 3 . The data in Tables 2 and 3 show that only about one third of the bulk sulfur content (16.9-18.2 wt.\%) can be found on the surface of the samples (5.3-5.6). Most of the sulfate groups in the catalysts with lower surface area are inaccessible for the reactant, whereas the sulfate groups on the samples with higher surface area can be found in the mesopores and can act as Brönsted acid centers essential for esterification reaction. 
FT-IR spectra of adsorbed pyridine are presented in Fig. 6. FT-IR spectra of sulfated samples contain bands characteristic of both Lewis and Brönsted acid sites (Fig. 6). The protonated Py molecules coordinated to the conjugated base of the solid Brönsted acid (Py-B) exhibit bands at $1537 \mathrm{~cm}^{-1}$ and $1640 \mathrm{~cm}^{-1}$. The Brönsted acidity of the sulfated $\mathrm{ZrO}_{2}$ samples prepared at $100^{\circ} \mathrm{C}$ is higher than that of prepared at $140^{\circ} \mathrm{C}$. FT-IR data of Py desorbed at higher temperature is characteristic for the strength of acid sites of the samples. Integrated intensity data for Py desorbed at 100,200 and $300^{\circ} \mathrm{C}$ can be found in Table 4 . It can be seen that the area of Brönsted acid band and the calculated $\mathrm{B} / \mathrm{L}$ ratio are higher for $\mathrm{SO}_{4}{ }^{2-} / \mathrm{ZrO}_{2}(100) \mathrm{T}$ and $\mathrm{SO}_{4}{ }^{2-} / \mathrm{ZrO}_{2}(100)$. The calculated of $\mathrm{B} / \mathrm{L}$ ratio increase at higher temperature but this effect is less pronounced for the $\mathrm{SO}_{4}{ }^{2-}$ $/ \mathrm{ZrO}_{2}(100) \mathrm{T}$ and $\mathrm{SO}_{4}{ }^{2-} / \mathrm{ZrO}_{2}(100)$ samples, indicating the presence of high concentration of strong Brönsted acid sites (Table 4).
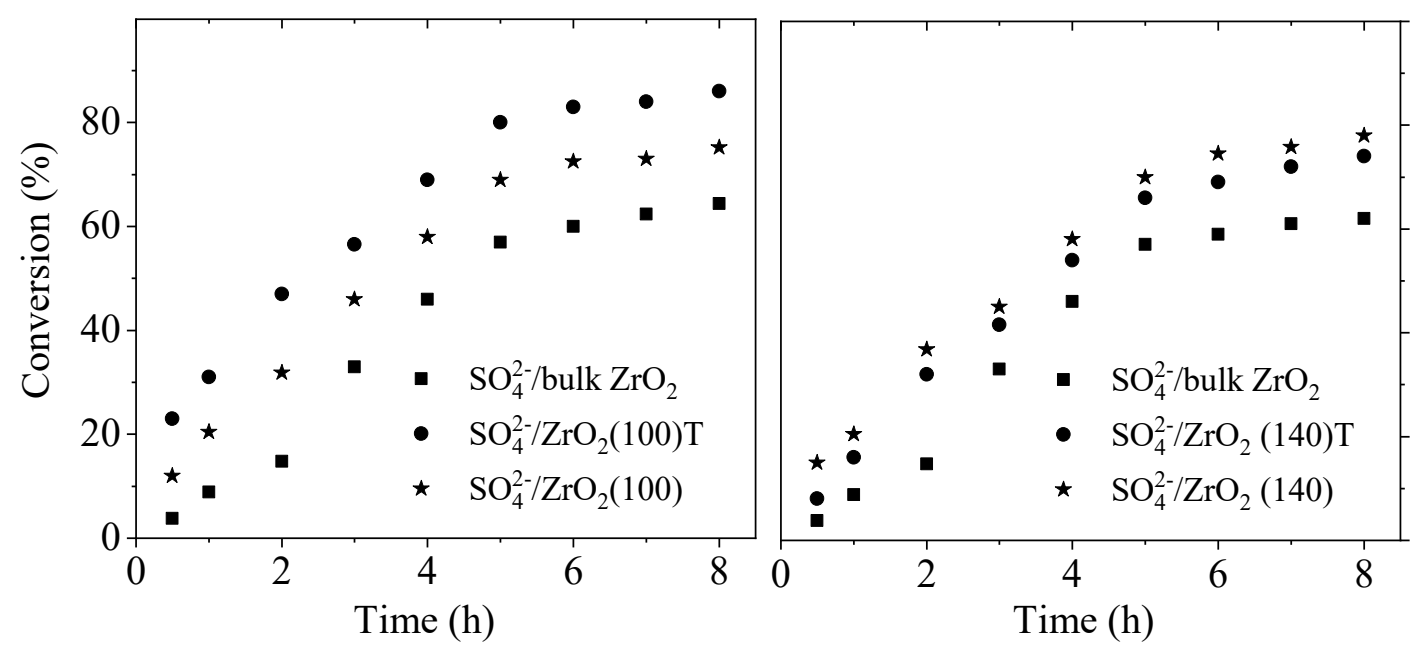

Fig. 7 Catalytic activity of sulfated zirconia catalysts in levulinic acid esterification with ethanol. Reaction conditions: reaction temperature $-70^{\circ} \mathrm{C} ; 2 \mathrm{~g}$ LA and $0.050 \mathrm{~g}$ catalyst $(2.5 \mathrm{wt} \%$ catalyst/LA); LA/ethanol weight ratio - 1:5. 


\subsection{Catalytic activity for LA esterification with ethanol}

The catalytic activity of the sulfated and none sulfated mesoporous $\mathrm{ZrO}_{2}$ nanoparticles was studied in esterification of levulinic acid with ethanol. The only registered products are ethyl levulinate and water. Non-sulfated $\mathrm{ZrO}_{2}$ samples show very low catalytic activity (around $1.5-2 \%$ after $5 \mathrm{~h}$ of reaction) (not shown). The sulfation treatment of the Zr-containing samples leads to a significant increase in the catalytic activity (Fig. 7). The highest catalytic activity was observed for sulfated $\mathrm{ZrO}_{2}$ sample, obtained by hydrothermal synthesis at $100^{\circ} \mathrm{C}$ with template. The result could be attributed to the higher concentration of strong acid sites (Table 3) and the higher surface area (Table 2) of this sample assuring the high zirconia dispersion even at high calcination temperature $\left(500^{\circ} \mathrm{C}\right)$ after sulfation procedure. The obtained sulfated $\mathrm{ZrO}_{2}$ samples show much higher catalytic activity than the sulfated bulk $\mathrm{ZrO}_{2}$ sample. The hydrothermal synthesis at a lower temperature $\left(100^{\circ} \mathrm{C}\right)$ in the presence of template favors the formation of smaller $\mathrm{ZrO}_{2}$ particles with size of 1-2 $\mathrm{nm}$, which has additional positive effect on the dispersion of sulfate groups on the mesoporous $\mathrm{ZrO}_{2}$. Despite the equal particles size $(5-6 \mathrm{~nm})$ of sulfated $\mathrm{ZrO}_{2}$ nanoparticles, synthesized at $140^{\circ} \mathrm{C}$ with or without template, the $\mathrm{SO}_{4}{ }^{2-} / \mathrm{ZrO}_{2}(140) \mathrm{T}$ shows higher catalytic activity because of its higher concentration of Brönsted acid sites and higher surface area compared to its analog, synthesized without template. It seems that both particle size and surface area have significant effect on the formation of acid sites and therefore on their activity in levulinic acid esterification.

With the $\mathrm{SO}_{4}{ }^{2-} / \mathrm{ZrO}_{2}(100) \mathrm{T}$ catalyst more than $80 \%$ of LA conversion can be achieved, a higher value than the one obtained by similar type of catalysts in the open literature $[6,15,34,35]$. The $\mathrm{SO}_{4}{ }^{2-} / \mathrm{ZrO}_{2}$ sample [6] shows $9 \%$ conversion of $\mathrm{LA}$ to ethyl levulinate at the same reaction conditions $\left(70^{\circ} \mathrm{C}, 8 \mathrm{~h}\right.$ reaction time, ethanol/LA molar ratio of 5:1, $2.5 \mathrm{wt} . \%$ of catalyst $)$. The sulfated $\mathrm{Si}$ doped $\mathrm{ZrO}_{2}$ sample shows much higher catalytic activity even at the applied reaction conditions $\left(\mathrm{T}=70^{\circ} \mathrm{C}, \mathrm{LA}: \mathrm{EtOH}=1: 10,10.0\right.$ wt. $\%$ of catalyst $)$, where much higher amount of catalyst was applied. The higher catalytic activity of our $\mathrm{SO}_{4}{ }^{2-} / \mathrm{ZrO}_{2}(100) \mathrm{T}$ sample can be explained by the high surface area, which can assure good accessibility of reactant molecules to the active 
sites. The main problem of the sulfated zirconia samples is their reusability, which is of key importance for practical applications. A negligible activity decrease was registered after 3 reaction cycles on the $\mathrm{SO}_{4}{ }^{2-} / \mathrm{ZrO}_{2}(100) \mathrm{T}$ sample $-86 \%$ after $8 \mathrm{~h}$ reaction time with fresh catalyst, compared to $81 \%$ after $5 \mathrm{~h}$ reaction time in 3 reaction cycles. The less pronounced leaching of sulfate groups registered on the $\mathrm{SO}_{4}{ }^{2-} / \mathrm{ZrO}_{2}(100) \mathrm{T}$ sample after the catalytic experiment, registered by $\mathrm{TG}$ analysis (Table 2), compared to the other studied samples could be a possible reason for its stable catalytic activity. The use of template for the synthesis of mesoporous $\mathrm{ZrO}_{2}$ nanoparticles favors the formation of active sites assuring the excellent catalytic performance of the catalysts in the studied reaction.

\section{Conclusions}

Zirconia nanomaterials were prepared by hydrothermal method at two reaction temperatures (100 and $140^{\circ} \mathrm{C}$ ) with or without template assistance and were modified by post synthesis method with sulfate groups. The synthesis temperature and the presence of template are of great importance for the preparation of nanosised $\mathrm{ZrO}_{2}$ with high surface area and better catalytic performance in esterification of levulinic acid with ethanol. Sulfated $\mathrm{ZrO}_{2}$ catalyst obtained by template-assisted hydrothermal synthesis at $100^{\circ} \mathrm{C}$ followed by sulfation and calcination at $500^{\circ} \mathrm{C}$ showed the highest catalytic activity among all investigated catalyst amounting to $86 \%$ of ethyl levulinate after $8 \mathrm{~h}$ of reaction time. The obtained nanosized $\mathrm{ZrO}_{2}$ materials are promising catalysts for the heterogeneous esterification of levulinic acid.

\section{Acknowledgements}

Financial support from the COST action FP 1306, ДКОСТ 01/21 and by the Bulgarian-Hungarian Inter-Academic Exchange Agreement is greatly acknowledged. 


\section{References}

[1] R. Luque, J. Campelo and J. Clark, Handbook of biofuels production: Processes and technologies, (Woodhead Publishing Series in Energy No. 15, 2013).

[2] Geilen FMA, Engendahl B, Harwardt A, Marquardt W, Klankermayer J, Leitner W (2010) Angew. Chem Int Ed 49:5510.

[3] Lin CSK, Pfaltzgraff LA, Herrero-Davila L, Mubofu EB, Abderrahim S, Clark JH, Koutinas

A, Kopsahelis N, Stamatelatou K, Dickson F, Thankappan S, Mohamed Z, Brocklesby R, Luque R, (2013) Energy Environ Sci 6:426.

[4] Corma A, Iborra S, Velty A (2007) Chem Rev 107:2411-2502.

[5] Chheda JN, Huber GW, Dumesic JA (2007) Angew Chem Int Ed 46:7164-7183.

[6] Fernandes DR, Rocha AS, Mai EF, Mota CJA, Teixeira da Silva V (2012) Appl Catal A 425426:199-204.

[7] Clark JH, Budarin V, Dugmore Th, Luque R (2008) Catal Commun 9:1709.

[8] Chen X-R, Ju Y-H, Mou C-Y (2007) J Phys Chem C 111:18731.

[9] Peterson AA, Vogel F, Lachance RP, Fröling M, Antal Jr.MJ, Tester JW (2008) Energy Environ Sci 1:32.

[10] Zakzeski J, Bruijnincx PCA, Jongerius AL, Weckhuysen BM, Chem Rev 110 (2010) 35523599.

[11] Lange J-P, Price R, Ayoub PM, Louis J, Petrus L, Clarke L, Gosselink H, (2010) Angew Chem Int Ed 49:4479-4483.

[12] Kuwahara Y, Fujitani T, Yamashita H (2014) Catal Today 237:18.

[13] Parvulescu V, Coman S, Grange P, Parvulescu VI (1999) Appl. Catal. A 176:27.

[14] Melero JA, Morales G, Iglesias J, Paniagua M, Hernández B, Penedo S (2013) Appl Catal A $466: 116$.

[15] Kuwahara Y, Kaburagi W, Nemoto K (2014) Appl Catal A 476:186-196.

[16] Yadav GD, Yadav AR, (2014) Chemical Eng J 243:556. 
[17] Zhang J, Wu ShB, Li B, Zhang HD (2012) ChemCatChem 4(9):1230.

[18] Bezergianni S, Dimitriadis A (2013) Renewable and Sustainable Energy Reviews 21:110.

[19] Patil CR, Niphadkar PS, Bokade VV, Joshi PN (2014) Catal Commun 43:188.

[20] Pasquale G, Vázquez P, Romanelli G, Baronetti G (2012) Catal Commun 18:115.

[21] Dutta S, De S, Saha B (2013) Biomass and bioenergy 55:355-369.

[22] Pileidis FD, Tabassum M, Coutts S, Titirici M-M, Chinese (2014) J Catal 35 (6):929-936.

[23] Trens Ph, Hudson MJ, Denoyel R (1998) J Mater Chem 8(9):2147.

[24] Serrano DP, Calleja G, Pizarro P, Gálvez P (2014) International journal of hydrogen energy 39:4812.

[25] Rumplecker A, Kleitz F, Li W, Salabas EL, Schüth F (2007) Chem Mater 19:485-96.)

[26] Gu D, Schüth F (2014) Chem Soc Rev 43:313.

[27] Ardizzone S, Bianchi CL, Grassi E (1998) Coll Surf A: Physicochemical and Engineering Aspects 135:41.

[28] Arata K, Hino M, Yamagata N (1990) Bull. Chem Soc Jpn 63:244.

[29] Tichit D, El Alami D, Figueras F (1996) J Catal 163:18.

[30] Ward DA, Ko EI, (1994) J Catal 150:18.

[31] Clearfield A, Serrette GPD, Khazi-Syed AH (1994) Catal Today 20:295.

[32] Ecormier MA, Wilson K, Lee AF (2003) J Catal 215:57.

[33] Hino M, Kurashige M, Matsuhashi H, Arata K (2006) Thermochimica Acta 441:35.

[34] Cirujano FG, Corma A, Llabrés i Xamena FX, (2015) Chemical Engineering Science 124 (3):52.

[35] Nandiwale KY, Yadava SK, Bokade VV (2014) Journal of Energy Chemistry 23 (4):535. 
Table 1 Physico-chemical properties of the studied mesoporous $\mathrm{ZrO}_{2}$ nanoparticles

\begin{tabular}{lcccc}
\hline Samples & $\begin{array}{c}\text { Crystallite size } \\
(\mathrm{nm})\end{array}$ & $\begin{array}{c}\text { S } \\
\left(\mathrm{m}^{2} / \mathrm{g}\right)\end{array}$ & $\begin{array}{c}\text { Pore Volume } \\
\left(\mathrm{cm}^{3} / \mathrm{g}\right)\end{array}$ & $\begin{array}{c}\mathrm{PD}^{\mathrm{b}} \\
(\mathrm{nm})\end{array}$ \\
\hline $\mathrm{ZrO}_{2}(100)$ & 5 & 190 & 0.30 & 5.4 \\
$\mathrm{ZrO}_{2}(100) \mathrm{T}$ & $1-2$ & 263 & 0.44 & 5.2 \\
$\mathrm{ZrO}_{2}(140)$ & $6-7$ & 150 & 0.30 & 5.3 \\
$\mathrm{ZrO}_{2}(140) \mathrm{T}$ & $6-7$ & 196 & 0.36 & 5.6 \\
\hline${ }^{\mathrm{a}}$ derived from XRD by applying Scherrer equation; ${ }^{\mathrm{b}}$ average pore diameter determined by BJH \\
method.
\end{tabular}

Table 2 Physico-chemical properties of the mesoporous sulfated $\mathrm{ZrO}_{2}$ nanoparticles

\begin{tabular}{|c|c|c|c|c|c|c|c|}
\hline Samples & $\begin{array}{c}\mathrm{S}_{\mathrm{BET}} \\
\left(\mathrm{m}^{2} / \mathrm{g}\right)\end{array}$ & $\begin{array}{c}\text { Pore } \\
\text { Volume } \\
\left(\mathrm{cm}^{3} / \mathrm{g}\right)\end{array}$ & $\begin{array}{l}\mathrm{PD}^{\mathrm{a}} \\
(\mathrm{nm})\end{array}$ & $\begin{array}{l}\mathrm{SO}_{4}^{2-} \\
\text { cont. }^{\mathrm{b}} \\
\text { (wt.\%) }\end{array}$ & $\begin{array}{c}\mathrm{SO}_{4}{ }^{2-} \\
\text { cont. } / \mathrm{S}_{\mathrm{BE}} \\
\mathrm{T}\end{array}$ & $\begin{array}{l}\text { S cont }{ }^{\mathrm{c}} \\
(\text { wt. } \%)\end{array}$ & $\begin{array}{l}\mathrm{SO}_{4}{ }^{2-} \\
\text { cont. } \\
\text { (wt. } \% \text { ) }\end{array}$ \\
\hline $\begin{array}{l}\mathrm{SO}_{4}^{2-} \\
/ \mathrm{ZrO}_{2}(100)\end{array}$ & 120 & 0.30 & 5.3 & 35.0 & 0.44 & 11.7 & 43.5 \\
\hline $\begin{array}{l}\mathrm{SO}_{4}{ }^{2-} \\
/ \mathrm{ZrO}_{2}(100) \mathrm{T}\end{array}$ & 252 & 0.40 & 5.2 & 35.8 & 0.21 & 12.0 & 49.5 \\
\hline $\begin{array}{l}\mathrm{SO}_{4}^{2-} \\
/ \mathrm{ZrO}_{2}(140)\end{array}$ & 83 & 0.25 & 5.3 & 33.7 & 0.61 & 11.2 & 43.6 \\
\hline $\begin{array}{l}\mathrm{SO}_{4}{ }^{2-} \\
/ \mathrm{ZrO}_{2}(140) \mathrm{T}\end{array}$ & 115 & 0.30 & 5.5 & 36.4 & 0.47 & 12.1 & 48.2 \\
\hline $\begin{array}{l}\mathrm{SO}_{4}^{2-} \\
/ \mathrm{bulkZrO}_{2}\end{array}$ & 5 & - & - & 33.6 & 10.1 & 11.2 & 24.8 \\
\hline
\end{tabular}

Table 3 XPS parameters of the studied $\mathrm{SO}_{4}{ }^{2-} / \mathrm{ZrO}_{2}$ samples

\begin{tabular}{|c|c|c|c|c|c|c|c|c|c|}
\hline \multirow[b]{2}{*}{ Samples } & \multirow{2}{*}{$\begin{array}{c}\mathrm{Zr} \\
\text { (at. \%) }\end{array}$} & \multirow{2}{*}{$\begin{array}{c}\mathrm{O} \\
\text { (at. \%) }\end{array}$} & \multicolumn{2}{|c|}{$\mathrm{S}$} & \multirow[b]{2}{*}{$\mathrm{S} / \mathrm{Zr}$} & \multirow[b]{2}{*}{$\mathrm{O} / \mathrm{Zr}$} & \multicolumn{3}{|c|}{ Components of Zr3d peak } \\
\hline & & & (at.\%) & (wt.\%) & & & $\begin{array}{c}\mathrm{Zr} 3 \mathrm{~d} \\
(182.6 \mathrm{eV})\end{array}$ & $\begin{array}{c}\mathrm{Zr} \mathrm{3d} \\
(184.2 \mathrm{eV})\end{array}$ & $\begin{array}{c}\operatorname{Zr} 3 \mathrm{~d} \\
(186.3 \mathrm{eV})\end{array}$ \\
\hline $\begin{array}{l}\mathrm{SO}_{4}{ }^{2-} \\
/ \mathrm{ZrO}_{2}(100) \mathrm{T}\end{array}$ & 8.3 & 75.1 & 16.6 & 5.3 & 2.0 & 9.0 & 15.3 & 84.7 & 0 \\
\hline $\begin{array}{l}\mathrm{SO}_{4}{ }^{2-} \\
/ \mathrm{ZrO}_{2}(140) \mathrm{T}\end{array}$ & 7.9 & 74.6 & 17.5 & 5.6 & 2.2 & 9.4 & 0 & 100 & 0 \\
\hline $\mathrm{SO}_{4}{ }^{2-} / \mathrm{ZrO}_{2}(140)$ & 7.5 & 75.2 & 17.3 & 5.5 & 2.3 & 10.0 & 0 & 63.5 & 36.5 \\
\hline
\end{tabular}


Table 4 Acidity of sulfated samples determined by FT-IR spectroscopy of adsorbed pyridine

\begin{tabular}{lcccc}
\hline Samples & $\begin{array}{c}\text { Py des. } \\
\text { temperature/ } \\
\text { C }\end{array}$ & $\begin{array}{c}\text { Area of Lewis acid } \\
\text { band }\left(1447 \mathrm{~cm}^{-1}\right)\end{array}$ & $\begin{array}{c}\text { Area of Brönsted acid } \\
\text { band }\left(1538 \mathrm{~cm}^{-1}\right)\end{array}$ & $\mathrm{B} / \mathrm{L}$ \\
\hline $\mathrm{SO}_{4}{ }^{2-}$ & 100 & 0.023 & 0.417 & 18.1 \\
$/ \mathrm{ZrO}_{2}(140)$ & 200 & 0.010 & 0.336 & 33.6 \\
& 300 & 0.009 & 0.254 & 28.2 \\
\hline $\mathrm{SO}_{4}{ }^{2-}$ & 100 & 0.045 & 0.549 & 12.2 \\
$/ \mathrm{ZrO}_{2}(140) \mathrm{T}$ & 200 & 0.018 & 0.475 & 26.4 \\
& 300 & 0.005 & 0.380 & 76.0 \\
\hline $\mathrm{SO}_{4}{ }^{2-}$ & 100 & 0.107 & 0.604 & 5.6 \\
$/ \mathrm{ZrO}_{2}(100)$ & 200 & & & 6.7 \\
& 300 & 0.076 & 0.509 & 6.5 \\
\hline $\mathrm{SO}_{4}{ }^{2-}$ & 100 & 0.062 & 0.402 & 6.4 \\
$/ \mathrm{ZrO}_{2}(100) \mathrm{T}$ & 200 & 0.098 & 0.622 & 9.6 \\
& 300 & 0.053 & 0.511 & 9.9 \\
\hline
\end{tabular}

